\title{
Editorial: Vitamin D Binding Protein, Total and Free Vitamin D Levels in Different Physiological and Pathophysiological Conditions
}

\author{
Zhongjian Xie ${ }^{1 *}$, Xiangbing Wang ${ }^{2}$ and Daniel D. Bikle ${ }^{3}$ \\ ${ }^{1}$ Hunan Provincial Key Laboratory of Metabolic Bone Diseases, National Clinical Research Center for Metabolic Diseases, \\ Department of Metabolism and Endocrinology, The Second Xiangya Hospital of Central South University, Changsha, China, \\ ${ }^{2}$ Division of Endocrinology, Metabolism and Nutrition, Rutgers University-Robert Wood Johnson Medical School, \\ New Brunswick, NJ, United States, ${ }^{3}$ Endocrine Unit, Veterans Affairs Medical Center, University of California, San Francisco, \\ San Francisco, CA, United States
}

Keywords: vitamin $D$ binding protein, total 25 -hydroxyvitamin $D$, free 25 -hydroxyvitamin $D, 1,25$-dihydroxyvitamin D, bioavailable 25-hydroxyvitamin D

\section{Editorial on the Research Topic}

Vitamin D Binding Protein, Total and Free Vitamin D Levels in Different Physiological and Pathophysiological Conditions

Vitamin D binding protein (DBP) is a major plasma carrier for vitamin D and its metabolites. In recent years, there has been growing interest in understanding the physiological functions and attributes of DBP. The current issue is comprised of five review articles and two original research papers concerning the physiology of DBP and its role in different disorders.

Poor vitamin D status is highly prevalent in many different countries (1-4), but the

Edited and reviewed by:

Jonathan H. Tobias,

University of Bristol, United Kingdom

${ }^{*}$ Correspondence:

Zhongjian Xie

zhongjian.xie@csu.edu.cn

Specialty section:

This article was submitted to

Bone Research,

a section of the journal

Frontiers in Endocrinology

Received: 13 January 2020

Accepted: 22 January 2020

Published: 11 February 2020

Citation:

Xie Z, Wang $X$ and Bikle DD (2020) Editorial: Vitamin D Binding Protein,

Total and Free Vitamin D Levels in

Different Physiological and

Pathophysiological Conditions.

Front. Endocrinol. 11:40.

doi: 10.3389/fendo.2020.00040 exact definition of vitamin $\mathrm{D}$ status is controversial. The plasma concentration of total 25-hydroxyvitamin D $[25(\mathrm{OH}) \mathrm{D}]$ is currently used as an indicator of vitamin $\mathrm{D}$ status. In the past decades, however, there has been argument as to whether just measuring total $25(\mathrm{OH}) \mathrm{D}$ is appropriate for the assessment of vitamin D status in different physiological and pathophysiological conditions $(5,6)$. About $85 \%$ of the total circulating $25(\mathrm{OH}) \mathrm{D}$ is bound to $\mathrm{DBP}$, and $15 \%$ is bound to albumin. About $0.03 \%$ of $25(\mathrm{OH}) \mathrm{D}$ circulates in free form. Since $25(\mathrm{OH}) \mathrm{D}$ is weakly bound to albumin and dissociates from it during tissue perfusion, the sum of the free and the albumin-bound $25(\mathrm{OH}) \mathrm{D}$ represents the bioavailable $25(\mathrm{OH}) \mathrm{D}$, which may be readily available for metabolic function. In contrast, the DBP-bound vitamin D is relatively unavailable to target tissue, with the exception of a few tissues such as the kidney that express a megalin/cubilin transport system for DBP-bound 25(OH)D. The concept that it is the free hormone and not the DBPbound hormone that enters cells is known as the free hormone hypothesis. In the review by Bikle and Schwartz it is highlighted that the DBP level is regulated by estrogen, glucocorticoids, and inflammatory cytokines but not by vitamin $\mathrm{D}$ itself, and therefore, these regulators would affect levels of total $25(\mathrm{OH}) \mathrm{D}$. The review by Bikle and Schwartz focuses on the biological importance of DBP with emphasis on its regulation of total and free vitamin D metabolite levels in various clinical conditions. They also point out that attempts to calculate the free level using affinity constants generated in a normal individual along with measurement of DBP and total $25(\mathrm{OH}) \mathrm{D}$ have not accurately reflected directly measured free levels in a number of clinical conditions. The authors examine the impact of different clinical conditions as well as different DBP alleles on the relationship between total and free $25(\mathrm{OH}) \mathrm{D}$, using only data in which the free $25(\mathrm{OH}) \mathrm{D}$ 
level was directly measured. Following their previous review (7), the review by Chun et al. discussed a number of important questions including the following. Is the total 25(OH)D (bound plus free) or the unbound free $25(\mathrm{OH}) \mathrm{D}$ the crucial determinant of the non-classical actions of vitamin D? While DBP-bound $25(\mathrm{OH}) \mathrm{D}$ is important for renal handling of $25(\mathrm{OH}) \mathrm{D}$ and endocrine synthesis of $1,25(\mathrm{OH})_{2} \mathrm{D}$, how does DBP impact extrarenal synthesis of $1,25(\mathrm{OH})_{2} \mathrm{D}$ and subsequent $1,25(\mathrm{OH})_{2} \mathrm{D}$ actions? Are there pathophysiological contexts where total $25(\mathrm{OH}) \mathrm{D}$ and free $25(\mathrm{OH}) \mathrm{D}$ would diverge in value as a marker of vitamin $\mathrm{D}$ status? This review aims to introduce the concept of free $25(\mathrm{OH}) \mathrm{D}$ and the molecular biology and biochemistry of vitamin $\mathrm{D}$ and $\mathrm{DBP}$, which provides the context for free $25(\mathrm{OH}) \mathrm{D}$, and surveys in vitro, animal, and human studies taking free $25(\mathrm{OH}) \mathrm{D}$ into consideration.

Low DBP levels in patients with primary hyperparathyroidism (PHPT) were first reported in 2013 by Wang's group (8) and confirmed by Battista et al. (9). In the paper by Wang et al., the authors recruited 75 patients with PHPT and 75 healthy control subjects. In addition, 25 PHPT patients underwent parathyroidectomy and had a 3-month follow up visit. The results showed that serum DBP levels were lower in patients with PHPT but that parathyroidectomy restored DBP levels. Lower DBP levels may be one of the contributing factors of low total 25(OH)D level in PHPT patients, and the total 25(OH)D levels might not reflect true vitamin D status in patients with PHPT.

In the comprehensive review by Bouillon et al. it was noted that DBP was originally discovered as a highly polymorphic protein useful for population studies and originally called Groupspecific Component (GC). It is now known that DBP and GC are the same protein and appeared early in the evolution of vertebrates. DBP is genetically the oldest member of the albuminoid family (which includes albumin, $\alpha$-fetoprotein, and afamin, all involved in the transport of fatty acids or hormones). DBP has a single binding site for all vitamin $\mathrm{D}$ metabolites with a high affinity for $25(\mathrm{OH}) \mathrm{D}$, thereby creating a large pool of circulating $25(\mathrm{OH}) \mathrm{D}$, which prevents rapid vitamin $\mathrm{D}$ deficiency. The review also highlighted the roles of DBP in preventing the urinary loss of $25(\mathrm{OH}) \mathrm{D}$ and the formation of polymeric actin fibrils in the circulation after tissue damage. DBP also plays a minor role in transporting fatty acids. Based

\section{REFERENCES}

1. Xie Z, Xia W, Zhang Z, Wu W, Lu C, Tao S, et al. Prevalence of vitamin $\mathrm{D}$ inadequacy among chinese postmenopausal women: a nationwide, multicenter, cross-sectional study. Front Endocrinol. (2007) 9:782. doi: 10.3389/fendo.2018.00782

2. Hypponen E, Power C. Hypovitaminosis D in British adults at age $45 \mathrm{y}$ : nationwide cohort study of dietary and lifestyle predictors. Am J Clin Nutr. (2007) 85:860-8. doi: 10.1093/ajcn/85.3.860

3. Byun EJ, Heo J, Cho S, Lee HJD, Kim HS. Suboptimal vitamin D status in Korean adolescents: a nationwide study on its prevalence, risk factors including cotinine-verified smoking status and association with atopic dermatitis and asthma. BMJ Open. (2017) 7:e016409. doi: 10.1136/bmjopen-2017-016409 on the fact that the total concentrations of $25(\mathrm{OH}) \mathrm{D}$ and $1,25(\mathrm{OH})_{2} \mathrm{D}$ in DBP null mice or humans are extremely low but calcium and bone homeostasis remain normal, the "free hormone hypothesis" appears to apply to the vitamin D hormones, $25(\mathrm{OH}) \mathrm{D}$ or $1,25(\mathrm{OH})_{2} \mathrm{D}$, as it does to other steroid hormones and thyroid hormone.

Vitamin $\mathrm{D}$ is important for bone health but may also have extra-skeletal effects. Cunningham et al. examined vitamin $\mathrm{D}$ metabolites in serum samples from age- and weightmatched women with and without PCOS and reported results in their paper. The authors found that 25-hydroxy-3epiVitamin $\mathrm{D}_{3}, 25$-hydroxyvitamin $\mathrm{D}_{2}, 25$-hydroxyvitamin $\mathrm{D}_{3}$, and 24,25-dihydroxyvitamin $\mathrm{D}_{3}$, but not 1,25 -dihydroxyvitamin $\mathrm{D}_{3}$ $\left[1,25(\mathrm{OH})_{2} \mathrm{D}_{3}\right]$, were associated with embryo parameters. The data suggest that vitamin $\mathrm{D}$ metabolites other than $1,25(\mathrm{OH})_{2} \mathrm{D}_{3}$ are important in fertility. Kew, in his review assesses the fundamental role of DBP in neutrophilic inflammation and injury. As highlighted by Kew, DBP induces selective recruitment of neutrophils. DBP is also an extracellular scavenger for actin released from damaged/dead cells, and formation of DBP-actin complexes is an immediate host response to tissue injury. DBP bound to G-actin functions as an indirect but essential cofactor for neutrophil migration.

Vitamin D and DBP have immunological effects and may be important in the development of type 1 diabetes (T1DM). Moreover, low total $25(\mathrm{OH}) \mathrm{D}$ levels are associated with the development of type 2 diabetes (T2DM). However, there are no convincing data showing that vitamin $\mathrm{D}$ supplementation has an effect on the prevention of T2DM (10). The review by Jorde discusses the relations between DBP and total and free $25(\mathrm{OH}) \mathrm{D}$ in T1DM and T2DM.

\section{AUTHOR CONTRIBUTIONS}

All authors listed have made a substantial, direct and intellectual contribution to the work, and approved it for publication.

\section{FUNDING}

This study was supported by National Natural Science Foundation of China (81672646, 81471055).
4. Acherjya GK, Ali M, Tarafder K, Akhter N, Chowdhury MK, Islam DU, et al. Study of vitamin D deficiency among the apparently healthy population in Jashore, Bangladesh. Mymensingh Med J. (2019) 28:214-21.

5. Youselzadeh P, Shapese SA, Wang X. Vitamin D binding protein impact on 25-hydroxyvitamin D levels under different physiologic and pathologic conditions. Int J Endocrinol. (2014) 2014:981581. doi: 10.1155/2014/ 981581

6. Jassil N, Sharma A, Bikle DD, Wang X. Vitamin D binding protein and 25hydroxyvitamin D levels: emerging clinical applications. Endocr Pract. (2017) 23:605-61. doi: 10.4158/EP161604.RA

7. Chun RF, Peercy BE, Orwoll ES, Nielson CM, Adams JS, Hewison M. Vitamin D and DBP: the free hormone hypothesis revisited. I Steroid Biochem Mol Biol. (2014) 144 Pt A:132-7. doi: 10.1016/j.jsbmb.2013. 09.012 
8. Wang X, Shapses SA, Wei S, Sukumar D, Ghosh J. Vitamin D-binding protein levels in female patients with primary hyperparathyroidism. Endocr Pract. (2013) 19:609-13. doi: 10.4158/EP12371.OR

9. Battista C, Guarnieri V, Carnevale V, Baorda F, Pileri M, Garrubba M, et al. Vitamin D status in primary hyperparathyroidism: effect of genetic background. Endocrine. (2017) 55:266-72. doi: 10.1007/s12020-016-0974-x

10. Pittas AG, Dawson-Hughes B, Sheehan P, Ware JH, Knowler WC, Aroda VR, et al. Vitamin D Supplementation and Prevention of Type 2 Diabetes. N Engl J Med. (2019) 381:520-30. doi: 10.1056/NEJMoa19 00906
Conflict of Interest: The authors declare that the research was conducted in the absence of any commercial or financial relationships that could be construed as a potential conflict of interest.

Copyright (c) $2020 \mathrm{Xie}$, Wang and Bikle. This is an open-access article distributed under the terms of the Creative Commons Attribution License (CC BY). The use, distribution or reproduction in other forums is permitted, provided the original author(s) and the copyright owner(s) are credited and that the original publication in this journal is cited, in accordance with accepted academic practice. No use, distribution or reproduction is permitted which does not comply with these terms. 